\title{
Working Capital Management and Firm Listing Status
}

\author{
Seraina C. Anagnostopoulou* \\ Athens University of Economics and Business, Greece
}

This study comparatively examines the determinants of working capital management for listed vs. unlisted firms, and assesses the impact of this policy on profitability by focusing on the cash conversion cycle, a commonly used measure of working capital management. By using a large UK public and private firm sample, it is found that private firms have significantly lower cash conversion cycles than their public counterparts, and that traditional determinants of the cycle significantly differ between the two groups. The findings are robust to matching public and private firms according to a number of fundamental characteristics, allowing only for their listing status to differ. Results further indicate that the cash conversion cycle has a relatively stronger (negative) impact on operating profitability for private, compared to public firms. This is consistent with greater importance of efficient working capital management for firms with more restricted access to external financing. (JEL: G30, G31, G32, M40)

Keywords: working capital, cash conversion cycle, private firms, listing status

\section{Introduction}

A popular measure of the efficiency of corporate working capital (WC) management is a firm's cash conversion cycle $(C C C)$, which links the time needed by firms to collect cash from customers with the time necessary in order to repay suppliers into one single measure (Deloof, 2003). A shorter, compared to a longer, $C C C$ reduces the need for

\footnotetext{
* I am grateful to Professor Panayiotis Theodossiou (the Editor-in-Chief), Professor Laurence Booth (the Editor-in-Charge), and two anonymous referees for their useful comments and suggestions.
}

(Multinational Finance Journal, 2012, vol. 16, no. 3/4, pp. 261-301)

(C) Multinational Finance Society, a nonprofit corporation. All rights reserved. DOI: $10.17578 / 16-3 / 4-4$ 
securing financing, as it limits the possibility for a firm to have to finance possible gaps between cash receipts and payments. This study examines the relative $C C C$ policies of two groups of firms that differ from each other with respect to their access to external funding, and therefore in the ways that could possibly affect $C C C$ policies: these are public or listed firms vs. private or unlisted firms.

In relation to the financing environment for private firms, previous research has indicated that private firms are significantly more leveraged than public firms (Brav, 2009; Asker, Farre-Mensa and Ljungqvist, 2011), and also face a relatively higher cost of capital (Brav, 2009; Saunders and Steffen, 2011). Private firms further appear to have more problems with underinvestment than public firms, due to more constrained access to capital markets, and mostly depend on bank financing (Lenger, Ernstberger and Stiebal, 2011). At the same time, corporate operating policies, relating to the determination of the components of the $C C C$, are naturally connected to financing choices in case cash is needed to finance possible gaps between receipts and payments. Indeed, previous research has considered financing options and access to capital as key determinants of working capital policies (Baños-Caballero, García-Teruel and Martínez-Solano, 2010). Thus, if private firms have different sources available in order to cover their cash needs, this could in turn affect the relative length their $C C C \mathrm{~s}$ in comparison to the ones of public firms. In this context, the first scope of the paper is to investigate into the relative length of the $C C C$ s for public vs. private firms. The expectation is in favor of $C C C$ s being relatively shorter for private, rather than public, firms, as the former group is expected to have fewer funding options and more difficulty to cover possible gaps between receipts and payments, resulting in a need to have a shorter $C C C$.

Furthermore, good working capital management enhances firm flexibility and competitive advantage (Filbeck, Krueger and Preece, 2007). Previous research testifies a negative relation between the length of the CCC and profitability (Shin and Soenen, 1998; Deloof, 2003; Luo, Lee and Hwang, 2009), indicating that an aggressive or short CCC policy is positively reflected in profitability. If a firm has a shorter inventory cycle, a longer payables cycle, and a shorter receivables cycle, it can free up funds from day-to-day-operations and invest them into growth projects, so it relies less on external sources of funding or financial markets (Luo, Lee and Hwang, 2009). In this way, a firm's operating policy, relating to the determination of the components of the 
$C C C$, is naturally connected with financing decisions, and all previous factors may collectively affect profitability. As the financing decisions of private and public firms are naturally made under the different options in place due to the fewer sources of funds available for private firms, the second objective of this paper is to examine the impact of the $C C C$ on profitability for public and private firms. The theoretical expectation is in favor of the greater importance of WC management for the profitability of the group with more constrained access to external financing - i.e. private firms.

Therefore, this study examines, for the first time, the length and determinants of the $C C C$ for public vs. private firms and the impact of the cycle on the relative profitability of the two groups, for public and private firms from the UK during 2001-2009, given that there exists data on a natural private firm sample for this country. In accordance with theoretical expectations, it is first testified that private firms have significantly shorter $C C C$ s (and components of the $C C C$, i.e. number of days inventory, days accounts receivable, and days accounts payable) even after accounting for differences in size, leverage, performance, growth, and industry between the two groups, using a propensity score matching approach throughout the study, in accordance with previous research (Michaely and Roberts, 2012). Private matched firms are found to have a shorter average $C C C$ of about 56 days, as opposed to nearly 84 days for public matched firms. This result is further confirmed by repeating the analysis for the entire (unmatched) sample of all UK public and private firms. Thus, study findings indicate that it takes longer for public firms to receive cash from their customers, but at the same time they need, or are given, more time in order to repay their trade creditors, compared to private firms. This last finding is considered possibly consistent with the stricter credit policy offered by the creditors of private firms, in accordance with the higher levels of $d e b t$, higher cost of capital, and fewer available sources for raising capital for this group of firms, as testified by previous research.

There is then found a number of significant determinants of the $C C C$ for private firms, which are not, however, confirmed in the case of public firms. These determinants for private firms include leverage, asset tangibility, firm size, cash flow, profitability, and lagged values of the $C C C$. Past levels of the $C C C$ prove to be the only variable consistently significant for private and also public firms: a possible indication that both public and private firms may have a target $C C C$ to which they converge. 
In addition, it is testified that although all of the components of the $C C C$ significantly (and, in almost every case, negatively) relate to profitability for both private and public firms, confirming previous research regarding their sign, the length of the $C C C$ is slightly strongly associated with profitability for private, compared to public, firms. This finding, although weak, is consistent with a greater degree of importance of WC policy for firms with more restricted access to external financing, as low WC requirements minimize the need for obtaining external funding. Finally, study findings on a relatively shorter length of the $C C C$ for private vs. private firms, and on a slightly greater significance of the length of the $C C C$ for future profitability for private firms, are confirmed by repeating the analysis for matched public and private firms (according to country, industry, size, and other operating characteristics) for firms from the rest of EU 15 countries. This last finding confirms that evidence on shorter CCCs for private firms is by no means country-dependent, and it is interpreted as indicative of the strength of the impact of the listing status (and corresponding capital raising constraints) on the WC policies of listed vs. unlisted firms.

The rest of the paper is organized as follows. Section II contains a short review of the literature on the determinants of the $C C C$ and the effect of WC management on profitability. Section III discusses the research hypotheses and section IV describes the sample selection process. Section V presents the empirical findings and the study concludes with section VI.

\section{Literature Review}

The business decisions affecting the $C C C$ involve both operating and financing choices relating to inventory policy, the trade credit provided to customers or received by suppliers, and decisions in order to cover a possible cash gap resulting from a mismatch in the timing of receivables and payables. For example, a firm's decision to grant trade credit to its customers, in an effort to increase sales, is balanced against its need for cash (Molina and Preve, 2009), which would be more valuable if the firm has obligations that are imminently repayable. As pointed out by Moussawi et al. (2006), the majority of previous literature on the determinants and consequences of working capital management has focused on specific aspects of the CCC: mainly trade credit (Smith, 
1987; Long, Malitz and Ravid, 1993; Petersen and Rajan, 1997; Niskanen and Niskanen, 2006; Cuñat, 2007; García-Teruel and Martínez-Solano, 2010). However, another set of research has taken a more comprehensive approach to WC management, and has identified significant determinants of corporate $C C C$ s, which include firm growth opportunities and size, leverage, asset tangibility, and market performance (Moussawi et al., 2006; Baños-Caballero, García-Teruel and Martínez-Solano, 2010).

A shorter $C C C$ has been considered a component or contributing factor of business success (Johnson, 2010, on the success of Dell Corporation's approach), while a longer $C C C$ lag increases the need for WC investment (Deloof, 2003). Regarding the impact of the length of the $C C C$ on profitability, the length of a firm's $C C C$ can, in theory, affect profits both positively and negatively (García-Teruel and Martínez-Solano, 2007). On one hand, a large CCC may increase sales and minimize interruptions to business due to the scarcity of products and, as a consequence, increase profitability (Deloof, 2003; Baños-Caballero, García-Teruel and Martínez-Solano, 2010). In addition, granting trade credit may favor sales as well, as customers are able to test the product provided (Long, Malitz and Ravid, 1993). However, a shorter $C C C$ implies that a firm receives cash quickly and pays suppliers close to the due date; therefore, a shorter $C C C$ may indicate efficiency in internal operations and more available cash flow, and hence the existence of fewer liquidity problems (Gentry, Valdyanathan and Lee, 1990). This can be theoretically justified if a faster turnover rate in working capital is later translated into higher expected cash flows (Luo, Lee and Hwang, 2009). In addition, if the costs of higher investment in WC outweigh the benefits of holding higher levels of inventory and offering trade credit to customers, the length of the $C C C$ should negatively affect profitability (Deloof, 2003). Furthermore, longer $C C C$ s also reduce the firm's available flexibility to manage cash flows when the firm faces adverse economic conditions, as there exists the risk for the firm to be 'locked' into excessive inventories and uncollectible receivables, and it will therefore have to rely strongly on internally generated cash flows to repay obligations in time (Richards and Laughlin, 1980). According to Jose, Lancaster and Stevens, (1996), a low CCC reduces a firm's need for credit and increases its debt capacity. In this case, an aggressive or short $C C C$ policy by firms reduces their need to borrow and the requirements for obtaining working capital; they can therefore be more efficient. At this 
point, previous research indeed confirms a significantly negative relation between $C C C$ and profitability (Jose, Lancaster and Stevens, 1996; Shin and Soenen, 1998; Deloof, 2003; Moussawi et al., 2006; Luo, Lee and Hwang, 2009; García-Teruel and Martínez-Solano, 2007), indicating that an aggressive or short $C C C$ policy is positively reflected in profitability.

\section{Hypotheses Development}

Past research has identified a number of factors as important determinants of the $C C C$ : for example, size, financial leverage, growth opportunities, and the ability to generate internal cash flows (Baños-Caballero, García-Teruel and Martínez-Solano, 2010; Moussawi et al., 2006). However, public or publicly listed and private or unlisted firms have been found to differ from each other in terms of certain factors identified as determinants of the $C C C$ by previous research. These differences refer to higher leverage for private firms, a result mainly of high dependence on short-term debt (Brav, 2009; Asker, Farre-Mensa and Ljungqvist, 2011); lower size (Brav, 2009); and possibly growth opportunities, as firm listing status has been seen as a proxy for growth opportunities (Maksimovic, Phillips and Yang, 2010). At the same time, previous research has considered firm financing options and ease of access to capital to be important determinants of working capital policies (Baños-Caballero, García-Teruel and Martínez-Solano, 2010), while private vs. public firms, by definition, differ in terms of the external options available for financing, and have also been found to face a relatively higher cost of capital (Brav, 2009; Saunders and Steffen, 2011).

Past research has also made a distinction between WC management in large vs. small firms (small and medium enterprises, or SMEs). This is because small firms have been found to differ in terms of ownership, financial flexibility, market access, and level of information asymmetry, as well as taxability, depending on the jurisdiction (Sherr and Hulburt, 2001). As a shorter, compared to a longer, $C C C$ reduces the need for securing financing, the rationale for a specific focus on smaller firms has been justified by the higher market imperfections hypothesized for these firms (Rodríguez, 2006; Baños-Caballero, García-Teruel and Martínez-Solano, 2010). In addition, small firms have been considered to have fewer alternative sources for external financing available, while 
they are more dependent on short-term debt (Niskanen and Niskanen, 2006; Baños-Caballero, García-Teruel and Martínez-Solano, 2010) and the debt obtained by them comes at higher interest rates (Niskanen and Niskanen, 2006). At the same time, easy access to capital markets has been considered as a way to secure the necessary funding to cover possible WC gaps externally, without problems (Hill, Kelly and Highfield, 2010).

However, in the case of public vs. private firms, the former do have access to a public equity market due to their listing status, with corresponding implications for available sources of funding. When comparing public to private firms, the latter group has fewer options for securing capital if needed, which are not attributed to firm size, as in the case of small firms, but rather to the very characteristic of firm listing status. In this context, the first scope of the paper is to comparatively examine the $C C C$ (and its determinants) for listed vs. unlisted firms. The expectation is in favor of private firms having relatively shorter $C C C$ s than public, as private firms are faced with fewer funding options, a relatively higher cost of capital according to past research, and therefore more difficulty to cover possible gaps between receipts and payments, resulting in the need to have shorter $C C C$ s. This leads to the first hypothesis:

$\mathrm{H}_{1}$ : Private firms are expected to have a shorter $C C C$ than public firms.

At the same time, a shorter $C C C$ reduces the need for obtaining $d e b t$ and securing funding outside the firm (e.g. Deloof, 2003). So, if a firm has shorter inventory and receivables cycles and a longer payables cycle, it can free up funds from day-to-day operations and invest them into growth projects, so that it relies less on external financial markets (Luo, Lee and Hwang, 2009). Freed-up cash flows can then be dedicated to serving the strategic objectives of the firm, e.g. developing new products and engaging in positive net present value projects. As external sources of financing are not equivalent for unlisted vs. listed firms, it is expected that the strength of the impact of the $C C C$ on profitability could also differ between public and private firms. At this point, private firms have fewer sources of external financing, so they should be more dependent on internally generated funds; external finance can be more expensive than internal finance due to market imperfections 
(Baños-Caballero, García-Teruel and Martínez-Solano, 2010). In this setting, investment and financing decisions are interrelated and result in a $C C C$ that may or may not be optimal for profitability. Given that access to external funding is more restricted for private firms compared to public firms, there is expected to be a stronger association between $C C C$ and profitability for private firms compared to public firms, leading to the second research hypothesis:

$\mathrm{H}_{2}$ : The $C C C$ is more strongly associated with profitability for private, compared to public, firms.

When making comparisons between private and public firms, throughout the empirical elaboration of the study, use is made of a propensity score matched sample approach, following Michaely and Roberts (2012). This approach performs matching according to size, profitability, growth, leverage, and industry, (on a year-by-year basis) between public and private firms. By matching public and private firms according to a number of attributes, a one-to-one comparison is allowed between public and private firms in terms of very important firm characteristics, with the listing status left to remain an important difference.

This method further helps to avoid possible selection bias in the analysis and interpretation of the results, e.g. private firms not having shorter $C C C$ s than public firms due to higher financing constraints for the former group but just because a characteristic of firms going public is that they have longer $C C C \mathrm{~s}$, due, for example, to growth-related reasons. ${ }^{1}$ In addition, a manifestation of financial distress could be poor liquidity, which could be expressed in the form of a shorter $C C C$ for a group of firms. In such a case, matching by fundamental characteristics, in terms of specific size, growth, operating performance, financial leverage, and industry, and then performing a comparison between the $C C C$ s of public vs. private firms, ensures that differences in the results can be mainly attributed to differences in firm listing status, and not to alternative interpretations.

1. For example, a high-growth firm could increase its $C C C$ as a result of following a less strict credit policy towards its customers, thus increasing its collection period for accounts receivable, in an effort to boost sales. 


\section{Sample}

The initial sample for the study consisted of all public and private firms from $15 \mathrm{EU}$ countries firms included in the Amadeus database (compiled by Bureau van Dijk) ${ }^{2}$, which, in the case of private firms, had data on cash flow $^{3}$, a turnover and total assets (TA) above EUR 1 million, and at least 50 employees in their last reported financial statements. The reason for imposing criteria on minimum values for turnover, $T A$, and number of employees for private firms was to only include firms classified as medium or large, which are obliged to fully comply with EU Directives. ${ }^{4}$ Amadeus reports data for a rolling ten-year window, so the study sample covers the period 2001-2009. This initial selection process resulted in a total of 87,398 private firms and 6,247 public firms across Europe. Following Burgstahler, Hail and Leuz (2006) and Brav (2009), firms were included regardless of whether they were subsidiaries of other firms or whether their accounts were consolidated or not. ${ }^{5}$ In accordance with previous research (Burgstahler,

2. The Amadeus database contains comprehensive and comparable information on around 19 million companies across Europe (source: http://www.bvdinfo.com/Products/Company-Information/International/AMADEUS.aspx). It is compiled by Bureau van Dijk: also the creator and provider of the Bankscope, Orbis, Osiris, and Fame databases, among others. The financial statement data provided by Amadeus for a large set of European private and public companies is compiled from several well-established national information collectors according to Burgstahler, Hail and Leuz, (2006), who have also employed the Amadeus database in their pan-European public and private firm analysis, as have Lenger, Ernstberger and Stiebal, (2011).

3. The data availability criterion for data on cash flow (Profit for the period + Depreciation) was not imposed in the case of the Netherlands, as the Amadeus database does not include data for this item for this country.

4. For a detailed discussion on the need to exclude private firms classified as small enterprises, see Burgstahler, Hail and Leuz (2006), p. 992. Starting in 2005, to be classified as a medium enterprise a firm should have a headcount of above 50 employees and either a sales or a balance sheet total of above EUR 10 million, following the application of Recommendation 2003/361/EC. These thresholds were updated from a previous recommendation for sales to exceed EUR 5 million and $T A$ to be greater than 2.5 million (Burgstahler, Hail and Leuz, 2006). As a result, an observation is included if it satisfies the Burgstahler, Hail and Leuz (2006) criteria until 2004, and the updated Recommendation 2003/361/EC criteria from 2005 onwards. When data was downloaded for firms from countries not using the Euro as their currency (the UK, Denmark and Sweden), data was downloaded from Amadeus directly in Euros.

5. Amadeus provides consolidated financial statement data when this is available, and parent-only data otherwise (Burgstahler, Hail and Leuz, 2006, p. 992). Robustness checks 
Hail and Leuz, 2006; Brav, 2009; Lenger, Ernstberger and Stiebal, 2011), financial, utility, and public sector firms were further excluded (SIC codes in the 6000s, 4900-4941, and 9000s, respectively), as well as firms with no data on sector SIC codes and firms with no data on the accounting standards followed. Finally, private firms were excluded for which the reported legal form was not equal to the corporation or its national equivalents, as similar accounting rules between public and private firms only apply to corporations and do not cover partnerships or sole proprietorships (Burgstahler, Hail and Leuz, 2006). To ensure the results are not affected by extreme observations, the bottom and top $0.5 \%$ of the values for all variables were eliminated for public and private firms separately.

However, the calculation of the $C C C$ and its components are crucial variables for this study, so observations without enough data available in order to calculate the $C C C$ were excluded. This refers to data availability for sales, inventory, accounts receivable, accounts payable, and cost of goods sold (COGS). The criterion for data availability for the components of the $C C C$ limited the sample to a great extent, as data on COGS is not available for a significant number of firms in Amadeus, and not at all for firms from Italy, Spain, Portugal, and Austria. Data on COGS was also very limited for Belgium and Luxembourg. This sample selection process resulted in a total of 11,074 and 86,158 firm year observations for public and private firms, respectively, with the UK to be contributing to $46.46 \%$ of the public firm sample (or 5,145 observations), and to $76.92 \%$ (or 66,274 observations) of the private firm sample. Thus, this initial sample was very heavily dominated by UK firms, for reasons relating to data availability from Amadeus for items needed in order to calculate the $C C C$ for the rest of EU 15 countries. This way, it was decided to proceed by making use of the UK only as the sample market for this study, as this country proved to be the only one among EU 15 with a natural or comprehensive sample of public and private firms, with data available from Amadeus permitting the calculation of variables crucial for the conduction of the study. Nonetheless, the analysis will be repeated by also employing the more limited data from the rest of EU 15 countries through the use of matched public and private firm samples, in an effort to examine whether any

include repeating the entire analysis reported in the study by only examining consolidated financial statements, in order to eliminate subsidiaries of larger holding companies, following Michaely and Roberts (2012), with no great qualitative change in the direction of the results (more information provided in footnote 16). 
results are country-dependent, or if they can be extrapolated for public and private firms in general regardless of country of origin.

Apart from the criterion on data availability for $C C C$ calculation, the observations reported are data-dependent. Regarding industry classification, the study follows the 16-sector grouping by Cohen and Zarowin (2010) of two-digit SIC codes, with a few minor modifications. These involve first assigning the two-digit codes not included in the Cohen and Zarowin grouping into one of the 16 sectors compiled by them, then adding one more sector to assign to services firms, resulting in a total of 17 sectors. The exact sector grouping according to two-digit SIC codes is reported in appendix A.

Following Michaely and Roberts (2012), to mitigate possible sample selection bias when comparing public and private firms ${ }^{6}$, a propensity score matched sample is used (Rosenbaum and Rubin, 1983, 1985; Smith and Todd, 2005; Heckman, Ichimura and Todd, 1997). This approach can be seen as less restrictive than regression-based approaches because it does not assume a linear association between firm characteristics and the difference between public and private firms examined each time (Michaely and Roberts, 2012). In addition, the number of observations in the public and private firm samples is such that it is more likely to get closer matches for the public firms, compared to the private-firm sample (Michaely and Roberts, 2012). This matching procedure finds for each public firm-year-industry observation a corresponding private firm-year-industry observation that is statistically equivalent in terms of firm size (total assets), profitability (return on assets), leverage (total debt/total assets), and investment opportunities (sales growth). The selection of the specific fundamental variables is based on a similar propensity score matching approach for public and private firms to that employed by Michaely and Roberts $(2012)^{7}$, consistent with the fundamental factors expected to differ

6. For example, are listing status and the resulting differences in financing constraints because of this status the actual drivers of any possible results, or should findings be attributed to other fundamental differences between the two groups, e.g. differences in operating characteristics?

7. Following Michaely and Roberts (2012), the matching procedure employed is a one-to-one nearest neighbor matching with replacement, restricting attention to propensity scores falling in the common support of both groups of firms, as they do. In specific detail, a probit model regression is first estimated in which the dependent variable takes the value of 1 if the firm is public (treatment sample) and 0 if the firm is private (control sample), and independent variables include $L n T A, S g r, R O A$ and TD/TA, for firms satisfying the sample 
between the two groups, with an ability to differentially influence the determination of the $C C C$. This is because past research has considered all of these factors (leverage, profitability, firm size, growth) as significant determinants of the $C C C \mathrm{~s}$, on a stand-alone basis (Baños-Caballero, García-Teruel and Martínez-Solano, 2010). Furthermore, to fit the research design of this study, observations are further matched on year and industry. The result of the matching procedure is the creation of two samples: a public firm matched sample and a private firm matched sample according to all these attributes.

\section{Empirical Findings}

\section{A. The length of the CCC for public and private firms}

Table 1 presents the mean, median, minimum, and maximum values, and also the values for standard deviation (StDev), for the key variables and ratios for public and private UK firms, which satisfy the sample selection criteria, during 2001-2009. There are further reported results on the statistical significance of $t$ test on the equality of means, and Wilcoxon/Mann-Whitney test for medians, when making comparisons between public and private firms, next to the relevant variable mean or median value. Variable definitions are reported in appendix B.

The cash conversion cycle is defined as Number of days inventory + Number of days accounts receivable - Number of days accounts payable (definitions reported in appendix B). The calculation of the $C C C$ and the computation of its components exactly follow from Jose, Lancaster and Stevens (1996). Other studies have made use of more detailed information for the calculation of the $C C C$, e.g. firm purchases (Deloof, 2003). However, the items available from the Amadeus database make possible the use of a limited number of accounting items, i.e. sales, COGS, inventory, and accounts receivable and payable, in

\footnotetext{
selection criteria (variable definitions reported in appendix B). Using the predicted probabilities (propensity scores) from the previous regression, matches are then forced between public and private firms within year and industry (procedure outcome variable $=$ CCC) and the result is the creation of a public and a private firm matched sample, including 6,931 observations for the UK: 3,788 for public and 3,143 for private firms. By using the predicted propensity scores, each public firm-year-industry observation is matched to the corresponding private firm-year-industry observation, which minimizes the absolute value of the difference between the propensity scores, in line with Michaely and Roberts (2012).
} 


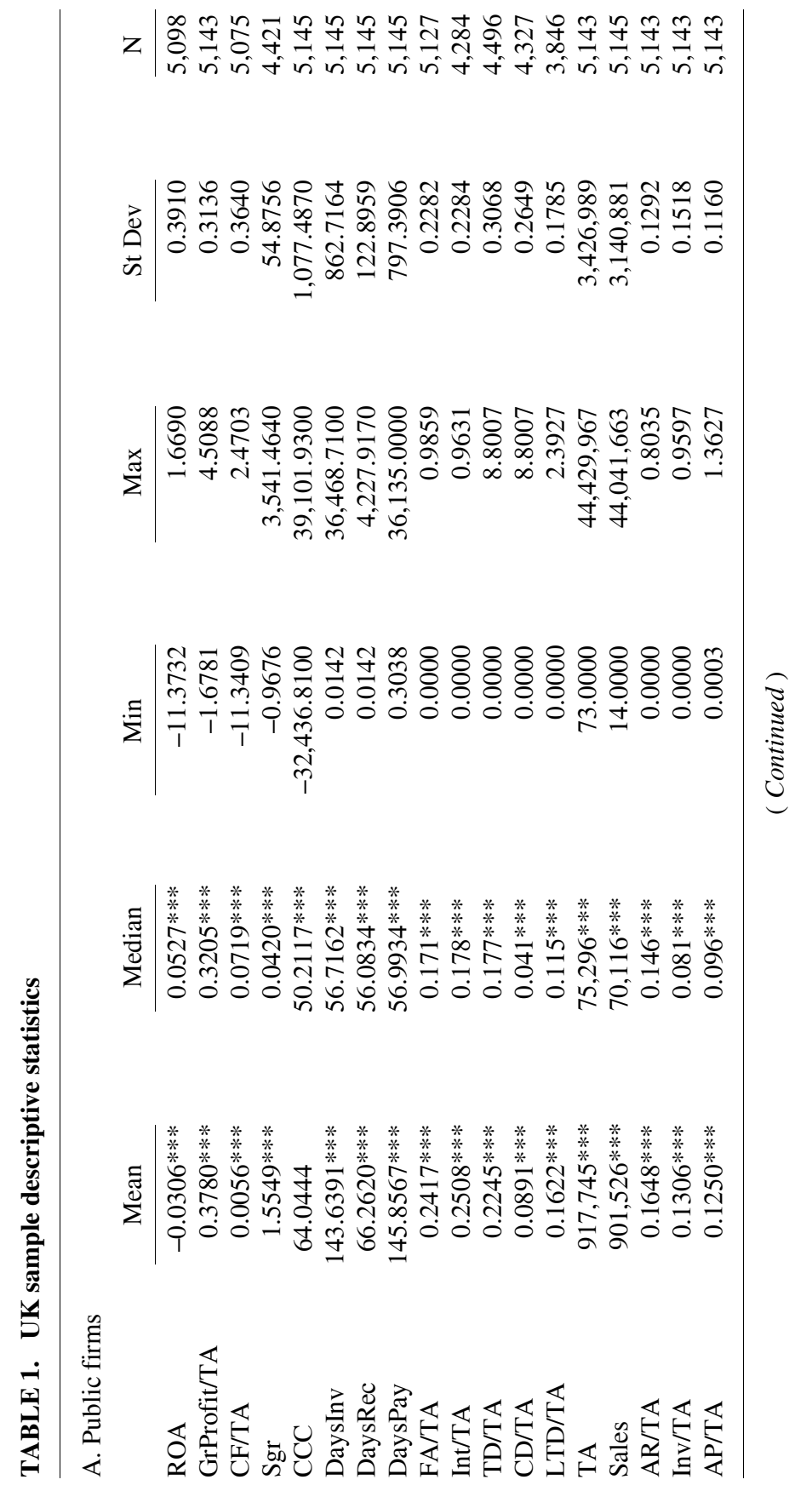




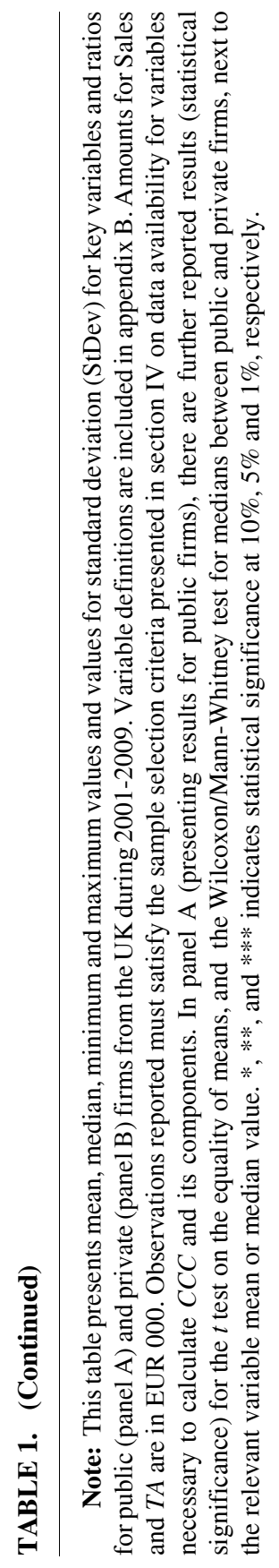


order to calculate the $C C C$. For this reason, the computation of the $C C C$ was adapted to items readily available for its calculation.

As can be observed from table 1 , UK private firms have a significantly shorter median $C C C$ than public firms, with values of 43.14 and 50.21 days, respectively (with mean values of 57.49 and 64.04 days). Private firms also have lower mean and median values of days in inventory and receivables, with 40.84 days in inventory vs. 56.72 for public firms, and about 47 vs. 56.08 days in accounts receivable (median values, with even larger mean values). Private firms are then observed to take a shorter amount of time in order to repay their obligations, with median values of 43.56 days, while 56.99 days are needed for public firms. All mean and median differences for the $C C C$ and its components (with the exception of mean values for the $C C C$ ) are significant at the $1 \%$ level between the two groups.

Broadly in accordance with prior research, private firms, as has been the case with small firms (Baños-Caballero, García-Teruel and Martínez-Solano, 2010), are observed to have a greater amount of their assets invested in working capital: their ratios of inventory and accounts receivable to assets exceed those of public firms ( $18.7 \%$ vs. $14.6 \%$ for accounts receivable and $12.5 \%$ vs. $8.1 \%$ for inventory using medians); the same occurs for accounts payable. Another interesting finding relates to the tangibility of assets owned by private and public firms, with the former group having a median value of $21.3 \%$ of assets in fixed tangible form, as opposed to $17.1 \%$ for public firms. The exact opposite occurs for intangible assets, with median values of $17.8 \%$ vs. $4.4 \%$ for public and private firms, respectively. These impressive differences, especially for intangible assets, are consistent with the higher leverage of private firms, as tangibility can be offered as collateral for debt, but, at the same time, could be reflective of intangible-intensive sectors (e.g. computers, according to untabulated results) being more prevalent among public firms.

Conforming to this intuition, private firms are smaller in terms of both total assets and sales than their public counterparts and further exhibit lower growth in terms of sales. Private UK firms are overall slightly (although significantly) more profitable in terms of $R O A$, $C F / T A^{8}$, and Gross Profit/TA. However, private firms are significantly

8. According to the definition given by Amadeus, cash flow is Profit for the period + Depreciation, where accrual accounting indicates that this calculation does not result in a purely cash flow measure. However, data on cash flow from operations is not available from the Amadeus database, so the study proceeds by making use of this cash flow approximation, 
more leveraged than public firms, which is the result mainly of short-term debt: private firms have median leverage ratios of about $27 \%$, compared to $18 \%$ for public firms. The main driver of this result is predominantly current (around 12\% for unlisted firms and $4 \%$ for listed firms, using median values) and not long-term debt, with the relevant long-term debt ratio taking values of about $11.5 \%$ for both groups.

Finally, despite the fact that truncation has been performed for both the public and private firm samples, the minimum and maximum values are extremely low or high for certain variables for both groups, indicating that the deduction of conclusions could probably be more reliable with the use of medians. When comparing the standard deviation of the variables for the two groups, there is no uniformity as to whether public or private firms get larger values, as this actually depends on the ratio compared each time. However, for the $C C C$ and its components in particular, relevant standard deviation values for public firms far exceed those of private firms, indicating a more uniform behavior for these variables among private firms. Overall, the descriptive statistics from table 1 indicate that the $C C C$ and its components significantly differ between private and public firms. In addition, the two groups are observed to significantly differ in terms of a number of factors underlined as possible determinants of the $C C C$ by previous research (Moussawi et al., 2006; Baños-Caballero, García-Teruel and Martínez-Solano, 2010): firm size, cash flow, leverage, growth, and asset tangibility.

Table 2 reports a comparison of key ratios between matched public firms (the treated sample) and private firms (the control sample), following the propensity score matching procedure described in the previous section. Mean values for key ratios are reported for the two matched samples, as well as the \% reduction in bias after performing the matching procedure and the values of the $t$-statistics (and corresponding $p$-values) when comparing the mean ratios or variable values of the two groups, following the matching procedure.

It is first observed from the table that differences in terms of $R O A$, sales growth, size (LnTA), and long term debt are statistically not significant between the two groups, indicating that the matching procedure has efficiently accounted for differences in these variables, so matched public and private firms are statistically indistinguishable in

in line with previous studies (e.g. Andrade and Kaplan, 1998). 
TABLE 2. Descriptive statistics for UK public and private matched firms

\begin{tabular}{|c|c|c|c|c|c|}
\hline \multirow[b]{2}{*}{ Variable } & \multicolumn{2}{|c|}{ Mean } & \multirow[b]{2}{*}{$\%$ bias } & \multicolumn{2}{|c|}{$t$-test } \\
\hline & Treated & Control & & $t$ & $p>t$ \\
\hline ROA & -0.0057 & -0.0036 & -0.8 & -0.36 & 0.715 \\
\hline Grprofit/TA & 0.3757 & 0.3257 & 16.9 & 7.63 & $0.000 * * *$ \\
\hline $\mathrm{CF} / \mathrm{TA}$ & 0.0244 & 0.0495 & -10.0 & -4.76 & $0.000 * * *$ \\
\hline ROE & -0.1046 & -0.0084 & -1.0 & -1.02 & 0.308 \\
\hline Sgr & 0.2801 & 0.2087 & 0.2 & 1.48 & 0.139 \\
\hline CCC & 83.5850 & 55.5100 & 4.0 & 1.70 & $0.089 *$ \\
\hline DaysInv & 136.7900 & 70.6070 & 10.2 & 4.39 & $0.000 * * *$ \\
\hline DaysRec & 62.7130 & 46.4320 & 19.5 & 8.51 & $0.000 * * *$ \\
\hline DaysPay & 115.9200 & 61.5290 & 14.1 & 5.94 & $0.000 * * *$ \\
\hline FA/TA & 0.2497 & 0.2500 & -0.2 & -0.07 & 0.947 \\
\hline IntTA & 0.2548 & 0.1274 & 64.4 & 21.10 & $0.000 * * *$ \\
\hline TD/TA & 0.2231 & 0.2403 & -4.1 & -2.53 & $0.011 * *$ \\
\hline CD/TA & 0.0883 & 0.1479 & -22.8 & -10.39 & $0.000 * * *$ \\
\hline LTD/TA & 0.1612 & 0.1654 & -1.1 & -0.78 & 0.433 \\
\hline LnTA & 11.5880 & 11.6020 & -0.8 & -0.34 & 0.735 \\
\hline EBITDA/S & -0.2132 & -0.0045 & -9.1 & -3.99 & $0.000 * * *$ \\
\hline
\end{tabular}

Note: This table reports a comparison of key ratios and/or variables between UK matched public firms (treated sample) and private firms (control sample), following the propensity score matching procedure described in section IV. There are reported mean values for key variables, the $\%$ reduction in bias after performing the propensity score matching procedure (according to size $(T A)$, leverage (TD/TA), profitability $(R O A)$, sales growth, year, and industry) and values of $t$-statistics (and corresponding $\mathrm{p}$-values) when performing a comparison between the mean ratio or variable values for the two matched (public and private) firm groups. Variable definitions are included in appendix B. *,**, and $* * *$ indicates statistical significance at $10 \%, 5 \%$ and $1 \%$, respectively.

terms of profitability, growth, size and long term debt. However, TD/TA does significantly differ between the two groups at $5 \%$ level, despite the fact that the mean values for the two groups are observed to be very close: $22.3 \%$ for public vs. $24 \%$ for private matched firms. In accordance with theoretical predictions, the $C C C$ and all of its components are observed to be significantly larger for public, compared to private, firms, confirming previous findings from table 1 for the entire public and private firm population. Matched public firms have a mean CCC of 83.585 days vs. 55.510 days for private firms. DaysInv, DaysRec, and DaysPay follow a similar pattern of behavior, with differences statistically significant at the $1 \%$ level in every case. In this way, regardless of whether public and private firms do not differ in terms of important fundamental characteristics, including growth, 
performance, size, and leverage, a significant tendency is confirmed for public firms to have longer $C C C$ s and also to take more days to sell their inventory, collect receivables, and repay their trade obligations.

Findings from table 2 indicate that private firms have significantly shorter $C C C$ s than public firms, in a possible effort to minimize their working capital investment needs. The interpretation of the finding that private firms have fewer days in payables than public firms can be twofold: private firms may need a shorter amount of time in order to repay their creditors, as more profitable firms can be expected to take less time to pay their bills (Deloof, 2003), which is also reasonable to expect upon considering that trade credit may come at higher interest rates than bank credit (Cuñat, 2007). An alternative explanation could be that private firms are offered less time by trade creditors in order to repay their bills, if the latter consider them to be less credit-worthy, given that they are more highly indebted borrowers, compared to public firms.

\section{B. Determinants of the CCC for private and public firms}

To examine the possible determinants of the $C C C$ for public and private firms, the following pooled panel data regression is estimated for UK public and private firms during 2001-2009:

$$
\begin{gathered}
C C C_{i t}=a_{0}+a_{1} \times P U B_{i t}+a_{2} \times C C C_{i t-1}+a_{3} \times S G R_{i t}+a_{4} \times \\
C F_{i t}+a_{5} \times D e b t_{i t}+a_{6} \times L n T A_{i t}+a_{7} \times F A_{i t}+a_{8} \times R O A_{i t}
\end{gathered}
$$

$C C C$ is the firm's Cash Conversion Cycle. $P U B$ is a dummy variable equal to 1 if the firm is public, and 0 if private. Debt equals TD/TA, $S G R$ is Sales Growth, LnTA equals the natural logarithm of TA, CF equals Cash Flow/TA, FA is Fixed Assets/TA and ROA equals EBIT/TA. The selection of regressors used in equation (1) is based on Baños-Caballero, García-Teruel and Martínez-Solano (2010). Variable definitions are reported in appendix B. Observations included in the regression must satisfy the sample selection criteria reported in section IV. As in Brav (2009), all regressors are multiplied by public and private firm dummy variables, Pub X and Priv X, where Pub X (Priv X) is the variable $\mathrm{X}$ interacted with a dummy equal to one (zero) if the firm is public and zero (one) if private. This empirical setting permits 
investigation within the same equation into differences between the factors that explain the cash ratios of public and private firms by simultaneously taking into account listed or unlisted firm status. ${ }^{9}$ Equation (1) is estimated with ordinary least squares and using heteroskedasticity-robust standard errors.

Equation (1) is estimated for both the matched and the raw public and private firm samples. The use of the matched sample is justified through the need to employ comparable public and private firms in the analysis, and isolate the impact of the listing status on $C C C$ policies. However, a counter argument on estimating equation (1) for matched public and private firms only could be on the usefulness of matching public and private firms according to size, profitability, leverage, and growth, when, at the same time, these factors have been identified as fundamental differences between public and private firms and have also been observed to be significant determinants of the $C C C$ in general by past research. In other words, this approach could end up over-controlling for differences between the two groups and missing possibly relevant information by over-treating relevant samples. For example, if public and private firms are matched according to leverage, is this variable expected to differentially affect the $C C C$ of the two groups of firms when estimating equation (1)? In this way, the matched samples are first used in the course of undertaking a descriptive comparative analysis, in order to ensure that differences in the results are mainly attributed to differences in listing status. In subsequent regression analyses, use is made of multiplicative regression terms (by multiplying a listing status variable with the fundamental variable in question each time), so the focus is again on the influence of listing status combined with the fundamental factor in question on the determination of the $C C C$, even if this factor takes comparable values for the two groups. Thus, equation (1) is first estimated for the matched public and private firm samples, and then re-estimated for the raw public and private firm sample, to ensure that no information on possible differential determinants of the $C C C$ for public vs. private firms is not missed or neutralized by focusing only on matched samples.

Table 4, panel A reports results when estimating equation (1) for matched public and private firms (using propensity score matching -

9. Estimating equation (1) for public and private firms separately does not produce any qualitative changes in the direction of the results (estimation results included in a previous version of the paper). 
exact estimation process described in section IV), and table 4 panel B reports relevant results when equation (1) is estimated for all public and private firms. ${ }^{10}$ Before proceeding with the presentation of the results on table 4, table 3 reports pair-wise Spearman rank correlation coefficients for key ratios for public (below the main diagonal) and private (above the main diagonal) UK matched firms during 2001-2009. For both public and private firms, negatively significant correlations are observed between profitability (defined as $R O A$ or $C F / T A$ ) and leverage (and its components). An impressive observation is the very high positive correlation between DaysInv and the CCC for public matched firms, with correlation coefficients above 0.7 significant at $1 \%$ level, indicating that the main driver of the $C C C$ for this group could be the ability to quickly sell inventory. For private firms, this exceptionally strong association is also confirmed with a correlation coefficient value of above $0.69 .{ }^{11}$

The results from panel A of table 4 indicate that, for public firms, the only consistently significant (positive) determinant of the $C C C$ is the past values of the variable. In the opposite direction, in the case of private firms, three additional regressors exhibit statistical significance. Lagged values of the $C C C$ and $R O A$ are both strongly significant positive determinants of the $C C C$ of private firms. The same occurs for cash flow and sales growth, with the coefficient for both variables to be (negatively) statistically significant. For private firms, a positive relation is observed between $R O A$ and the length of the $C C C$, indicating that profitable firms will tend to have a larger $C C C$. However, this finding could be partly due to a mechanical relation between higher sales (and accounts receivable) and profits. The internally generated cash flow regressor is not observed to negatively relate to the $C C C$ of private firms, indicating that private firms that are stronger in internal cash flow generation will tend to have shorter $C C C$, as improved internal liquidity

10. When equation (1) is estimated for the raw public and private firm sample (table 4 panel B), there are additionally included year dummy and industry sector dummy variables (for 17 industry sectors - definitions reported in appendix A), which are not reported among the results. Industry and year dummy variables are not included in regression estimations using the data for matched firms (table 4 panel A) to avoid double-controlling for these factors, as firm matching has been performed for all these attributes. Including relevant variables does not change the results qualitatively (untabulated results).

11. Calculating Pearson instead of Spearman correlation coefficients, or estimating correlation coefficients for the entire UK sample, instead of the matched UK public and private firm samples, does not change results qualitatively. 


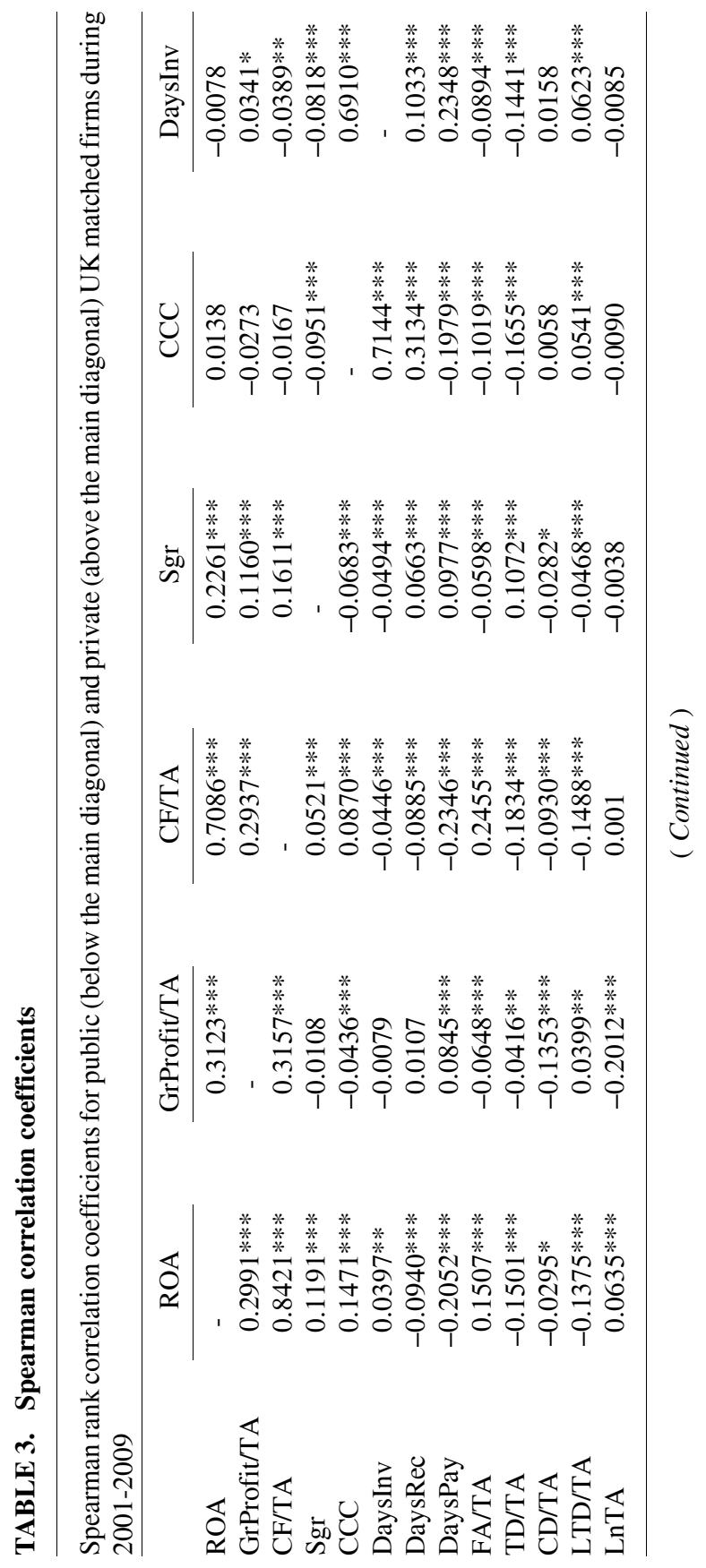




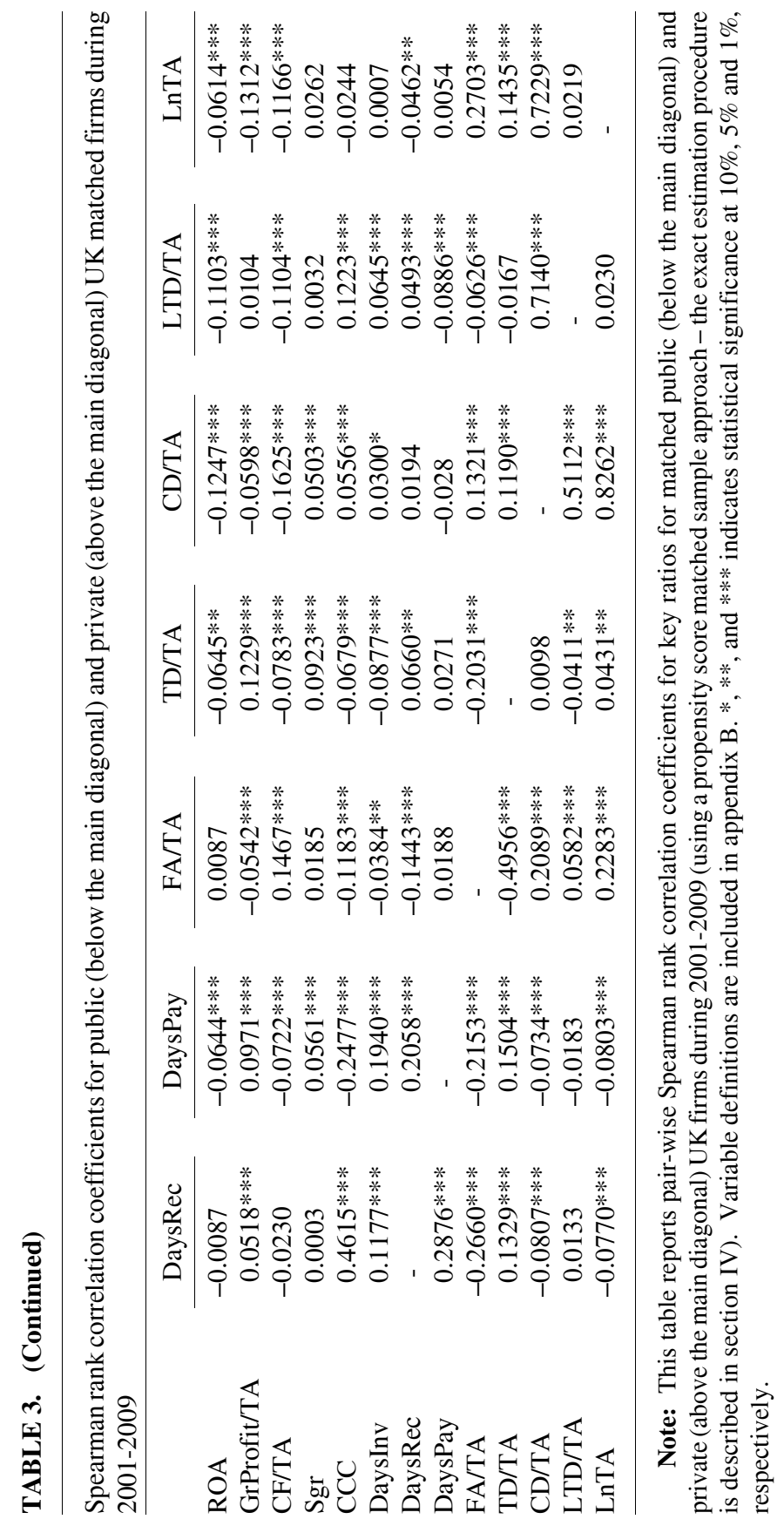


TABLE 4. The determinants of the Cash Conversion Cycle for public and private firms

A. Matched public and private firms

c

PUB

PubCCC $_{t-1}$

PrivCCC $_{t-1}$

PubSGR

PrivSGR

PubCF

PrivCF

PubLnTA

PrivLnTA

PubFA

PrivFA

PubROA

PrivROA

PubTD

PrivTD

R-squared

$\mathrm{F}$

Prob $>F$

$\mathrm{N}$

B. All public and private firms
$-5.8666$

112.9115

0.8305

1.0068

$-2.6877$

$-38.8081$

$-251.8581$

$-36.9226$

$-5.5549$

0.7927

$-44.9554$

9.3453

302.8182

33.4398

6.0238

2.1245

0.3803

24.8700

0.0000

6,549
$-0.40$

1.79

2.44

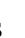

PUB

PubCCC $_{t-1}$

PrivCCC $_{t-1}$

PubSGR

PrivSGR

PubCF

PrivCF

PubLnTA

PrivLnTA

PubFA

PrivFA

PubROA

PrivROA

PubTD

PrivTD

R-squared

$\mathrm{F}$

Prob $>F$

N

9.4289
91.9464

0.8110

0.6198

2.4052

$-30.6251$

$-244.0851$

$-8.9711$

$-4.5504$

1.9365

$-45.3944$

$-33.3417$

242.9251

19.9372

$-12.1492$

4.4075

0.3815

261.1900

0.0000

52,858

( Continued)
11.68

$-0.09$

$-5.54$

$-1.05$

$-2.46$

$-1.58$

0.70

$-1.01$

1.07

1.29

2.81

0.21

0.38

$* * *$

***

**

$* * *$

***

0.92

1.69

2.43

4.66

0.40

$-5.71$

$-1.29$

$-1.79$

$-1.37$

2.83

$-1.04$

$-3.01$

1.35

4.86

$-0.35$

2.18

$* *$

*** 
TABLE 4. (Continued)

Note: This table reports regression results (coefficient and $t$-statistic values) for the following pooled panel data regression estimated for the UK for 2001-2009: $C C C_{i t}=a_{0}+a_{1}$ * $P U B_{i t}+a_{2} * C C C_{i t-1}+a_{3} * S G R_{i t}+a_{4} * C F_{i t}+a_{5} * D e b t_{i t}+a_{6} * L n T A_{i t}+a_{7} * F A_{i t}+a_{8} *$ $R O A_{i t} \cdot C C C$ is the Cash Conversion Cycle. $P U B$ is a dummy variable equal to 1 if the firm is public, and 0 if private. Debt equals TD/TA. SGR is Sales Growth, LnTA equals the natural logarithm of TA, $C F$ equals Cash Flow/TA, $F A$ is Fixed Assets/TA and ROA equals EBIT/TA. Variable definitions are reported in appendix B. Observations included in the regressions must satisfy the sample selection criteria presented in section IV, on data availability for variables necessary to calculate $C C C$ and its components. As in Brav (2009), all regressors are multiplied by public and private firm dummy variables, Pub X and Priv X. Pub X (Priv $\mathrm{X}$ ) is the variable $\mathrm{X}$ interacted with a dummy equal to $1(0)$ if the firm is public and 0 (1) if private. Panel A reports results for matched public and private firms (using a propensity score matched sample approach - the exact estimation procedure is described in section IV), and panel B for all public and private firms. Regressions are estimated with OLS and using heteroskedasticity-robust standard errors, and by adding year dummies and industry sector dummies for 17 industry sectors (reported in appendix A) when estimating results for all public and private firms in panel B. *,**, and *** indicates statistical significance at $10 \%$, $5 \%$ and $1 \%$, respectively.

may reduce working capital requirements (Baños-Caballero, García-Teruel and Martínez-Solano, 2010).

Firm listing status per se is found to positively relate to the length of the $C C C$ (at $10 \%$ significance level) in both panels $\mathrm{A}$ and $\mathrm{B}$ of table 4 , confirming the descriptive statistics from tables 1 and $2 .{ }^{12}$ Repeating the analysis undertaken in table 4, panel $\mathrm{A}$ by employing the raw or unmatched public and private firm sample in table 4 panel B confirms and extends results from panel A. While all statistically significant results from panel A are confirmed in panel B results, the latter further indicate that in general, firm size and leverage, whose effect on the $C C C$ could be partly neutralized in results from panel A because of employing a public and private firm sample matched according to these characteristics, positively and significantly relate to the length of the $C C C$ for private firms. When significant, the coefficient signs for private firms are in part consistent with evidence from previous studies

12. Equation (1) has been re-estimated (for panel B) by excluding the lagged $C C C$ and $S G R$ regressors, with no qualitative changes (but an increase in the number of observations, as all variables reflected the same calendar year). The results are also robust to excluding either the $C F$ or the $R O A$ regressors to mitigate multicollinearity concerns. Robustness checks include the addition of an IFRS dummy that is generally positive (and in some instances, significant) for private firms and not significant for public firms. No further controls are implemented for the accounting standards followed by public and private firms (IFRS vs. UK GAAP), as in the case of private firms, the vast majority of firms follow local GAAP. 
in the field. However, in contrast to findings by Baños-Caballero, García-Teruel and Martínez-Solano (2010) for small firms, it is found that leverage positively relates to the length of the $C C C$ for private firms. In other words, private firms that can secure bank lending, take advantage of it in order to increase their $C C C$, by granting, for example, more trade credit to their customers to be able to realize increases in sales. However, an alternative explanation could be that a firm may need to borrow more in order to finance a larger $C C C$. Larger private firms are also observed to have larger $C C C$ s, in accordance with findings by Moussawi et al. (2006): if firm size improves access to funding, then it should help a firm maintain a larger $C C C$.

In addition, table 4 panel $\mathrm{B}$ results show that asset tangibility for private firms negatively affects their $C C C$, consistent with Moussawi et al. (2006) and Baños-Caballero, García-Teruel and Martínez-Solano (2010), and supporting arguments by Fazzari and Petersen (1993) that there exists a trade-off between fixed capital investments and working capital investments in the presence of financial constraints. Overall, focusing on the results for actual (or unmatched) firms from table 4 indicates that a number of significant determinants of the $C C C$ exist for private firms, but generally not for public firms. These determinants for private firms include leverage, asset tangibility, firm size, cash flow, profitability, and lagged values of the $C C C$. This last variable proves to be the only one consistently significant for public firms, possibly indicating that both public and private firms may have a target $C C C$, balancing the costs and benefits for maintaining this target cycle (Baños-Caballero, García-Teruel and Martínez-Solano, 2010).

\section{The CCC and profitability for public and private firms}

To examine the impact of the $C C C$ on the profitability of public and private firms, the following pooled panel data regression is estimated for UK public and private firms during 2001-2009:

$$
\begin{aligned}
& \text { Gross Profit }_{i t}=a_{0}+a_{1} \times \text { PUB }_{i t}+a_{2} \times \text { Lev }_{i t}+a_{3} \times \text { LnTA }_{i t}+a_{4} \times F A_{i t} \\
& +a_{5} \times S R G_{i t}+a_{6} \times C C C_{i t} \text { or DaysInv } \\
& i t
\end{aligned}
$$

Gross Profit equals Gross Profit/TA. PUB is a dummy variable equal to 1 if the firm is public, and 0 if private. TD equals TD/TA. SGR is Sales 
Growth, LnTA equals the natural logarithm of TA, and FA is Fixed Assets/TA. CCC is the Cash Conversion Cycle, and DaysInv, DaysRec and DaysPay represent Days in Inventory, Accounts Receivable and Accounts Payable, respectively. Variable definitions are presented in appendix B; observations included in the regressions must satisfy the sample selection criteria presented in section IV. Table 5 reports results when estimating equation (2) for matched firms (using propensity score matching, following the exact estimation process described in section IV), while equation (2) is also estimated for the actual or unmatched public and private firm sample for robustness purposes (untabulated results). All regressors are multiplied by public and private firm dummy variables, Pub X and Priv X, as in Brav (2009), where Pub X (Priv X) is the variable $\mathrm{X}$ interacted with a dummy equal to one (zero) if the firm is public and zero (one) if private. ${ }^{13}$ Regressions are estimated with ordinary least squares and using heteroskedasticity-robust standard errors. The definition of profitability in terms of gross profit and the selection of the regressors used in equation (2) are consistent with Deloof (2003). The use of gross profit as a profitability measure is further justified by the fact that it refers to a core definition of profit that is inherently related to the components of the $C C C$.

It shown in table 5, when simultaneously taking listing status into account, that both firm size and asset tangibility negatively relate to gross profit for public and private firms, indicating that smaller firms and firms with fewer tangible assets show improved operating profitability. However, at this point, one has to bear in mind that profitability is defined by making use of gross profit, so its definition does not consider, for example, selling or administrative expenses, which could adversely affect bottom-line earnings for rapidly expanding firms. Neither debt nor sales growth is observed to be a significant determinant of profitability for public firms. The first, but not the second, result is confirmed in the case of private firms, for which sales growth is observed to be a positive contributor to grow profit, consistent with previous research (Deloof, 2003).

More importantly, it is observed from table 5, that for both public and private firms, the length of the $C C C$ is a significant and negative contributor to operating profitability. This indicates that, for both

13. Estimating equation (2) for public and private firms separately does not produce any qualitative changes in the direction of the results (estimation results included in a previous version of the paper). 


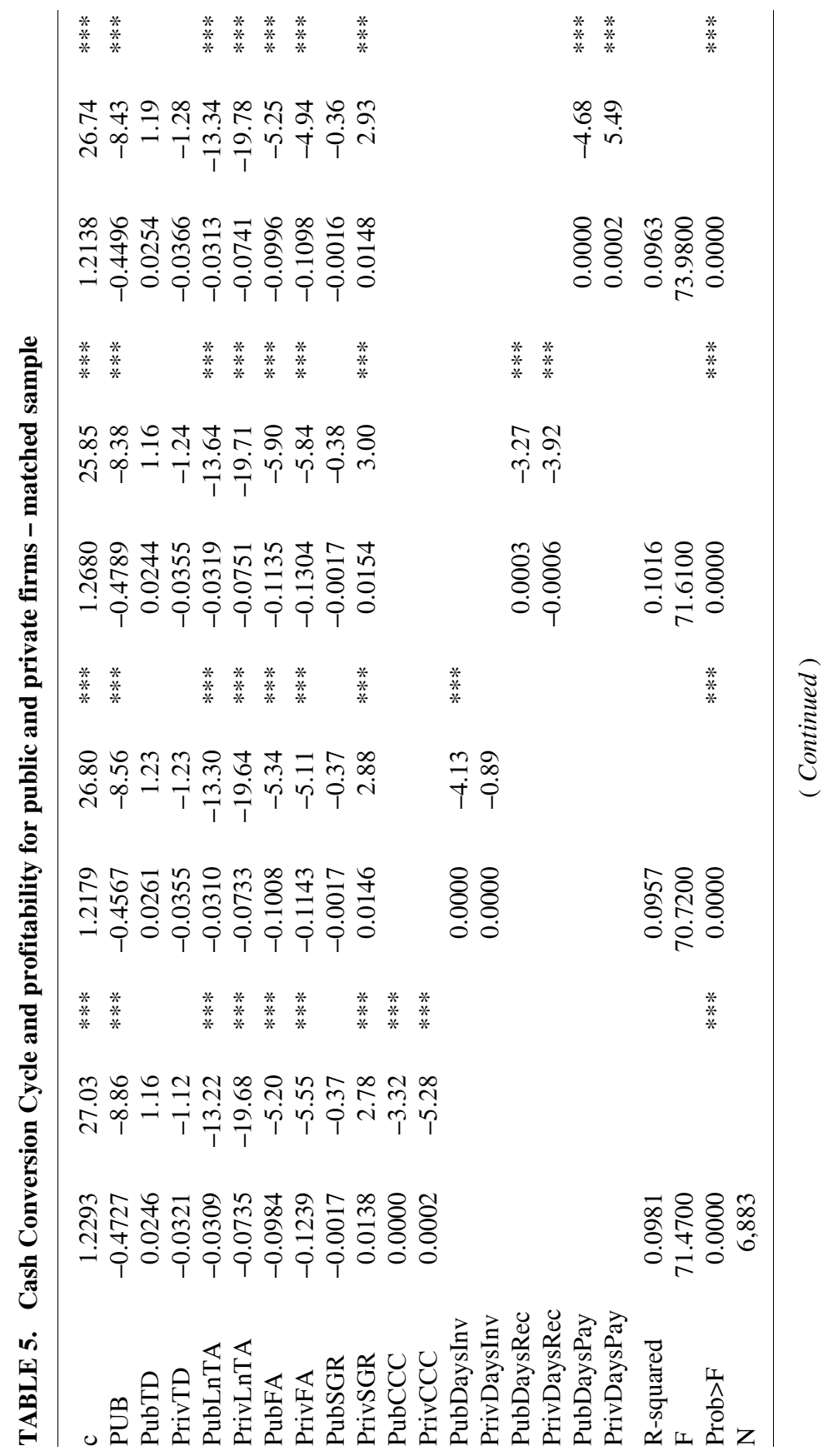




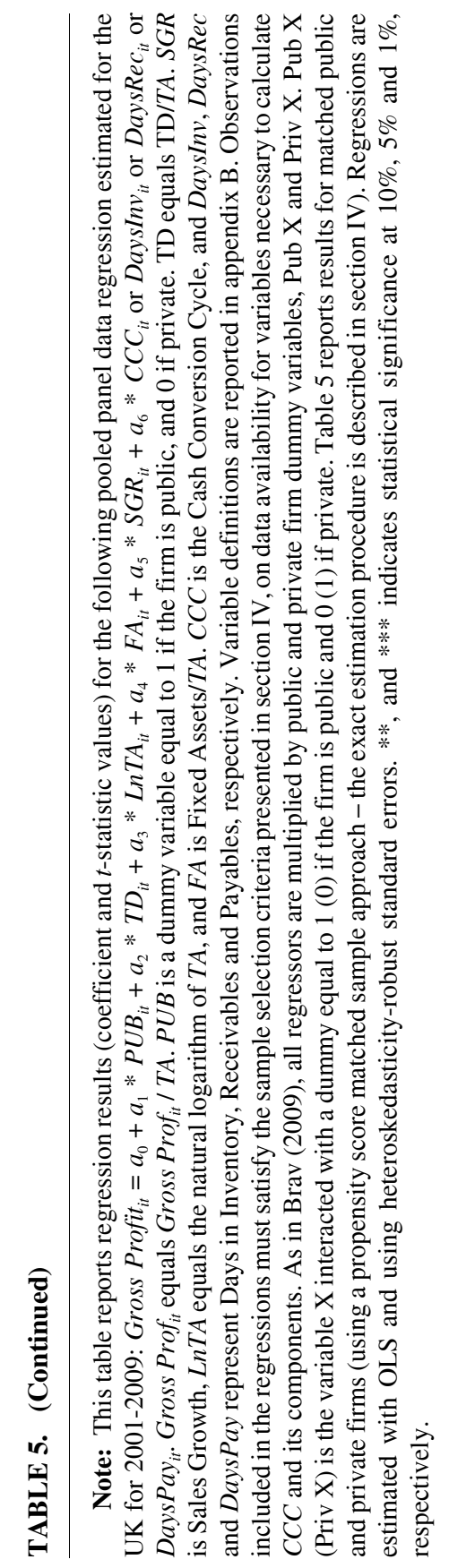


groups of firms, minimizing overall working capital investment positively relates to core profitability. However, the value of the t-statistic of the $C C C$ coefficient for public firms (-3.32) is lower, in absolute terms, than the one for private firms $(-5.28)$, and so is the value of the relevant coefficient of PubCCC, compared to PrivCCC (PubCCC value of -0.000016 vs. PrivCCC value of -0.000126 - result not explicitly apparent in table due to the lower number of decimal places reported). Performing a post-estimation comparison test on difference of the two coefficients PubCCC vs. PrivCCC yields an F-statistic of 22.55 (untabulated results), indicating that PrivCCC is significantly larger in absolute terms than PubCCC, or that the length of the $C C C$ is a slightly stronger determinant of future profitability for private vs. public firms. At this point, there cannot be ruled out the possibility that the negative association between WC management and profitability is actually a consequence of profitability, rather than the effect of it. This issue has also been acknowledged as a limitation of empirical research on WC management and profitability by previous research (Deloof, 2003), and it inherently affects this study as a limitation as well.

Regarding the behavior of the components of the $C C C$ for private firms, the number of days accounts receivable and days inventory exhibit a negative connection with gross profit, as is the case for public firms (although the effect of DaysRec on profitability is not significant for private firms. Interestingly, for private firms, the days accounts payable regressor is observed to positively and significantly affect profit. This is in contrast with findings by previous research, which generally testify to a negative association between accounts payable and profitability (Deloof, 2003; García-Teruel and Martínez-Solano, 2007), and also the findings from this study for public firms. This research justified the negative association between accounts payable and profitability under the argument that less profitable firms take longer to pay their bills (Deloof, 2003). However, for private, but not public firms, it is found that less profitable private firms actually take less time to pay their bills. Or, it could be that creditors provide more, as opposed to less, relaxed credit terms to less profitable private firms, assuming that a shorter time window provided for repaying creditors indicates stricter credit terms, another indication of the funding constraints faced by private vs. public firms. Estimating equation (2) for the raw (unmatched) sample of public and private firms does not change results qualitatively with respect to the influence of the $C C C$ and its 
components on future profitability (untabulated results). ${ }^{14,15,16}$

\section{The length of the CCC for public and private firms - rest of EU 15}

As explained in section IV, the use of the UK market as the study sample is justified by reasons of data reliability on a natural public and private firm sample, as there was found comprehensive data for the calculation of the $C C C$ for this country only, among other European (EU 15) countries. Existing research on the determinants and consequences of WC management mainly consists of country-specific studies (e.g. Deloof, 2003 for Belgium, or Baños-Caballero, García-Teruel and Martínez-Solano, 2010 for Spain). The rationale for this focus relates to the fact that legal, market, and institutional factors could be country-specific (La Porta et al., 1998). This focus, though, does not permit the generalization of any results, apart from the intuitive but untested expectation that other countries with similar institutional characteristics may exhibit similar results. Whether a model can be accurately transferred and applied to totally new data settings from different countries is an issue that is open for empirical validation (Ooghe and Balcaen, 2007), rather an issue of intuitive expectation.

Despite the possible representativeness problems that data from EU 15 countries other than the UK might represent, given that UK private firms were found to cover above $75 \%$ of EU 15 private firm-year

14. The only qualitative difference is the finding that DaysInv significantly relates to future profitability for public and private firms.

15. Equation (2) was re-estimated by adding a lagged regressor of the dependent variable and also by dropping the $S G R$ regressor, with no qualitative changes (but an increase in the number of observations, as all variables reflected the same time in terms of calendar year in the second case). The results are also robust to adding an IFRS dummy variable and using a one-year lag for all regressors.

16. The robustness tests (not tabulated) include repeating calculations using consolidated data for the results reported in all tables in order to exclude subsidiaries. This is because WC management could be different within a holding company compared to standalone firms. The direction of the results remains unchanged; however, the results are weaker than the ones reported, with a sharp reduction in the number of observations upon using consolidated statements, especially in the case of private firms. This aggravation could be due to a significant reduction in the size of the sample, as argued by Burgstahler, Hail and Leuz (2006) when they implement the same kind of robustness control (p. 1,011 - Footnote 37). In accordance with Burgstahler, Hail and Leuz (2006) and Brav (2009), the results are reported by employing the largest possible sample, which is the one including both consolidated and unconsolidated data, despite the existence of possible arguments in favor of not selecting this option. 


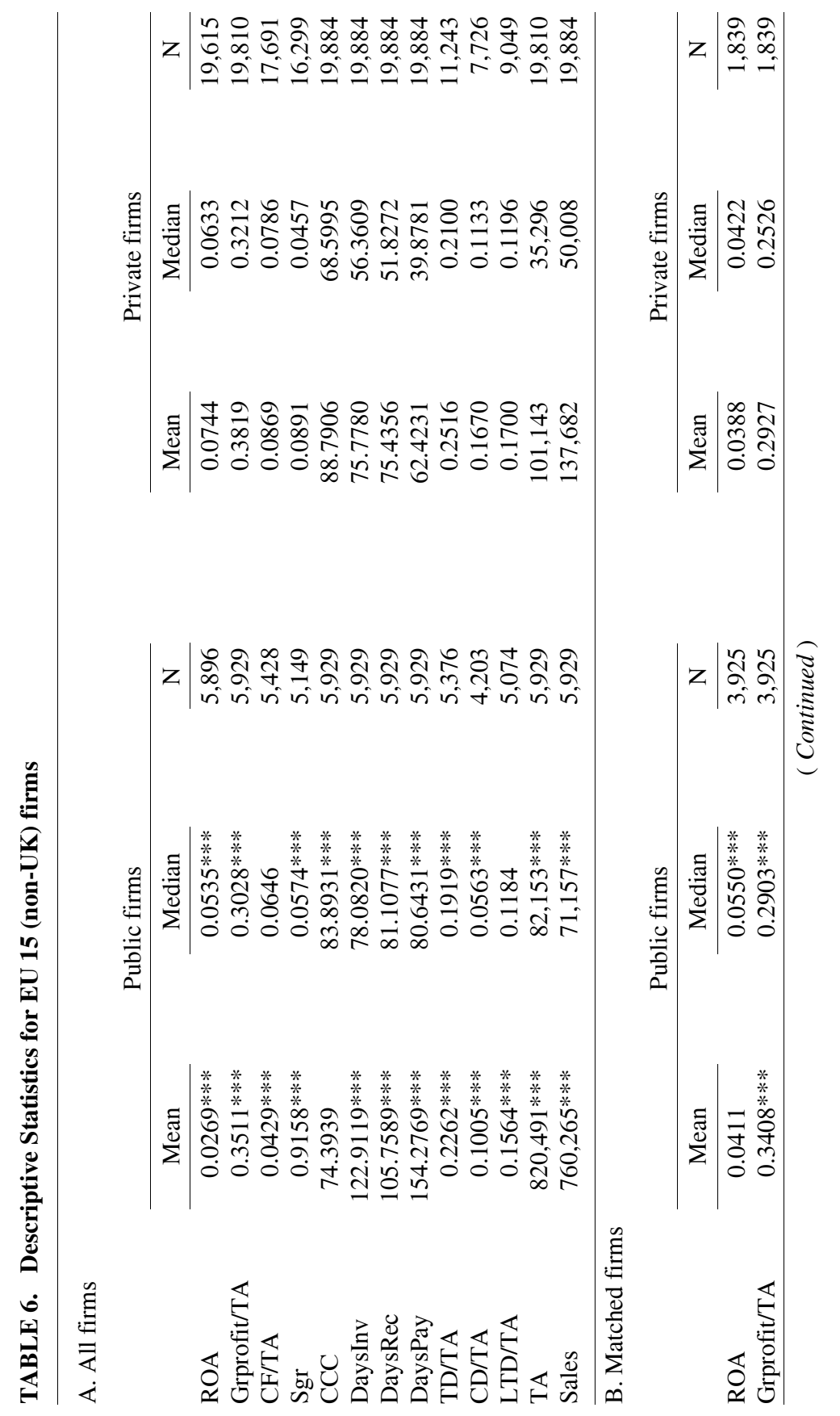




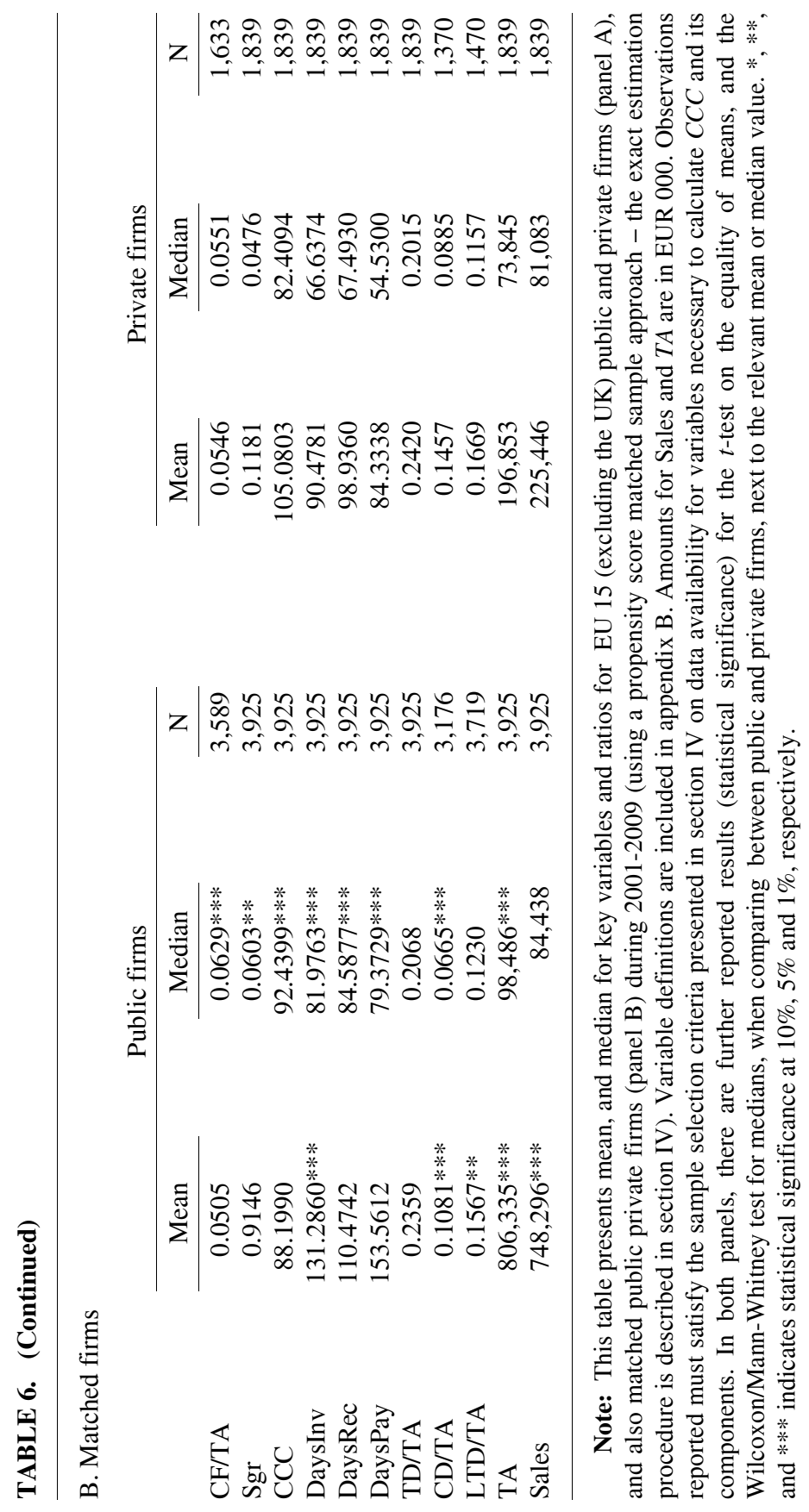


observations with data on the $C C C$ from Amadeus, as a final control, a brief part of the previous analysis was extended for the rest of EU 15 countries. In specific, there was performed propensity score matching in the exact same way as described in section IV for the rest of EU 15 countries satisfying the sample selection criteria, by using firm country as an additional criterion for matching. Table 6 reports descriptive statistics (and results on statistical significance) for key variables and ratios for EU 15 (excluding the UK) public and private firms (panel A), and matched public private firms (panel B) during 2001-2009.

There can be observed from table 6 that evidence on UK private firms having significantly lower CCCs (and its components) than public firms is by no means country-dependent. Regardless of whether an actual (table 6 panel A) or a matched (table 6 panel B) public and private firm sample is used, private firms are observed to have significantly lower $C C C$ s (and components of the $C C C$ ) than public firms, when making use of median values. The relevant result is not confirmed when observing mean values for the $C C C$, but comparative results are not statistically significant in the case of means for this variable. Finally, an interesting finding is the observation that key ratios and variables again significantly differ between public and private firms, a possible indication of fundamental differences expected to exist between the two groups due to their listing status, in accordance with past research (Brav, 2009). ${ }^{17}$

\section{Conclusion}

In this study, the determinants and consequences of working capital management are examined for listed vs. unlisted firms. This examination is performed by investigating the relative length, and determining factors for a commonly used proxy for WC management, the cash conversion cycle, and there is further assessment of the impact

17. All estimation results reported in this study have been repeated for the rest of EU 15 countries, with data available for the calculation of the $C C C$, and results do not change qualitatively, leading to the conclusion that findings for the UK are not country-dependent (untabulated results, included in a previous version of the paper). Interestingly, when estimating equation (2) for EU 15 public and private firms other than the UK, it is observed that the length of the $C C C$ does not significantly relate to future operating profitability for public firms, but does so for private ones. This finding is interpreted as further evidence on greater importance of efficient WC management (through the determination of the $C C C$ ) for private, compared to public firms. 
of the $C C C$ and its constituting factors on operating income. Motivation for the study is received from the fact that public and private firms naturally have access to different options and sources from which to secure external funding, while WC management involves operating decisions that are interrelated with financing decisions. This way, the expectation is in favor of private firms having shorter $C C C$ s than public firms, due to anticipated greater difficultly in covering possible financing gaps between cash receipts and payments as easily as would be the case for public firms.

For reasons of data availability for the calculation of the $C C C$, the study uses a sample of public and private firms from the UK during 2001-2009; it is first testified that private firms have significantly smaller median (and mean) CCCs than public firms. Private firms are also observed to exhibit lower values for all of the components of the $C C C$. Thus, private firms, with shorter $C C C$ s than public firms, are found to follow a policy regarding $C C C$ s that minimizes their working capital investment needs. This finding is robust due to the employment of a propensity score matched sample approach, performed by matching public and private firms according to size, leverage, performance, growth, and industry according to year.

The existence of a number of statistically significant determinants of the $C C C$ for private firms is also observed, though are not confirmed in the case of public firms. For private firms, these include leverage, asset tangibility, firm size, cash flow, profitability, and lagged values of the $C C C$. Past levels of the $C C C$ prove to be the only consistent determinant of the $C C C$ for both private and public firms. It is then found that, despite the fact that the components of the $C C C$ negatively and significantly relate to operating profitability for both private and public firms (with the exception of days accounts payable for private firms), the length of the $C C C$ is slightly more strongly (negatively) associated with profitability for private, as opposed to public, firms. This evidence, although weak, is consistent with the relatively stronger importance of WC policy for firms having more restricted access to external financing, i.e. private firms, as low requirements in WC minimize the need to obtain financing outside the firm.

Finally, despite limited data availability on variables necessary to calculate the CCC for EU 15 countries other than the UK, study findings on relatively shorter $C C C$ s for private vs. public firms, are confirmed when repeating the analysis for this (more limited) sample. This evidence leads to the conclusion that study findings are not 
country-dependent, and can be extrapolated for public and private firms in general, regardless of country of origin.

This study mainly contributes to previous research on two grounds. First, it examines, for the first time, the relative WC policies and their impact on profitability for public and private firms. The focus is on the effect of listing status on WC policy, whereas previous research has made a distinction based on firm size for the determination of WC management, rather than listing status. However, a firm's listing status represents a natural determinant of available funding sources and is applicable to the vast majority corporations that are unlisted. Second, study findings indicate that WC policy has a stronger impact on profit for the group with a more constrained access to capital, i.e. private firms. This finding underlines the importance of the availability of sources of funding for both financing and operating decisions, as WC policy relates to both of these decisions, for any groups of firms with differential access to funding.

Accepted by: Prof. P. Theodossiou, Editor-in-Chief, March 2013

\section{Appendix A}

17 sectors constructed following Cohen and Zarowin (2010), with additional assignment of the 2-digit codes not included in their 16 sectors grouping into one of 16 sectors, plus constructing a 17th sector consisting of firms from the services industry.

\begin{tabular}{|l|l|l|}
\hline $\begin{array}{c}\text { Sector Codes } \\
\text { Employed }\end{array}$ & \multicolumn{1}{|c|}{ Sector Names } & \multicolumn{1}{|c|}{$\begin{array}{c}\text { Corresponding } \\
\text { 2-digit SIC codes }\end{array}$} \\
\hline 1 & Oil and gas & $10,12,13,14,29$ \\
\hline 2 & Food products & $01,02,07,08,09,20$ \\
\hline 3 & Paper and paper products & $24-27$ \\
\hline 4 & Chemical products & 28 \\
\hline 5 & Manufacturing & $21-23,30-34$ \\
\hline
\end{tabular}




\begin{tabular}{|l|l|l|}
\hline 6 & $\begin{array}{l}\text { Computer equipment and } \\
\text { services }\end{array}$ & 35,73 \\
\hline 7 & Electronic equipment & 36 \\
\hline 8 & Transportation & $37,39,40-45,47$ \\
\hline 9 & Scientific instruments & 38 \\
\hline 10 & Communications & 48 \\
\hline 11 & $\begin{array}{l}\text { Electric, gas, and sanitary } \\
\text { services }\end{array}$ & 49 \\
\hline 12 & Durable goods & $15-17,46,50-51$ \\
\hline 13 & Retail & $52-57,59$ \\
\hline 14 & $\begin{array}{l}\text { Eating and drinking } \\
\text { establishments }\end{array}$ & 58 \\
\hline 15 & Entertainment services & $70,78,79,84$ \\
\hline 16 & Health & 80 \\
\hline 17 & Services & $\begin{array}{l}72,75,76,81-83, \\
86-88\end{array}$ \\
\hline
\end{tabular}

\section{Appendix B}

Items, abbreviations and definitions

\begin{tabular}{|l|l|}
\hline \multicolumn{1}{|c|}{ Item and abbreviation } & \multicolumn{1}{c|}{ Definition } \\
\hline Sales & Operating Revenue - Turnover \\
\hline$T A$ & Total Assets \\
\hline Inventory & Amadeus item 'Stock' \\
\hline Accounts Receivable & Amadeus item 'Debtors' \\
\hline
\end{tabular}




\begin{tabular}{|c|c|}
\hline Accounts Payable & Amadeus item 'Creditors' \\
\hline COGS & Cost of Goods Sold \\
\hline $\begin{array}{l}\text { Cash Conversion Cycle - } \\
C C C\end{array}$ & $\begin{array}{l}\text { Number of days inventory }+ \\
\text { Number of days accounts } \\
\text { receivable - Number of days } \\
\text { accounts payable }\end{array}$ \\
\hline $\begin{array}{l}\text { Number of days inventory - } \\
\text { DaysInv }\end{array}$ & Inventory/(COGS/365) \\
\hline $\begin{array}{l}\text { Number of days accounts } \\
\text { receivable-DaysRec }\end{array}$ & Accounts Receivable/(Sales/365) \\
\hline $\begin{array}{l}\text { Number of days accounts } \\
\text { payable - DaysPay }\end{array}$ & Accounts Payable/(COGS/365) \\
\hline $\begin{array}{l}\text { Cash Flow/Total Assets - } \\
C F / T A \text { or } C F\end{array}$ & $\begin{array}{l}\text { (Profit for the period }+ \\
\text { Depreciation)/Total Assets }\end{array}$ \\
\hline $\begin{array}{l}\text { Current Debt/Total Assets - } \\
\text { CD/TA }\end{array}$ & Loans/Total Assets \\
\hline $\begin{array}{l}\text { Long Term Debt/Total } \\
\text { Assets - LTD/TA }\end{array}$ & Long Term Debt/Total Assets \\
\hline $\begin{array}{l}\text { Total Debt/Total Assets - } \\
\text { TD/TA or } L E V\end{array}$ & $\begin{array}{l}(\text { Loans }+ \text { Long Term Debt }) / \text { Total } \\
\text { Assets }\end{array}$ \\
\hline Return on Assets - ROA & $\begin{array}{l}\text { Earnings before Interest and } \\
\text { Tax/Total Assets (EBIT/TA) }\end{array}$ \\
\hline $\begin{array}{l}\text { Gross Profit/Total Assets - } \\
\text { GrProfit/TA or GrProfit }\end{array}$ & $($ Sales-COGS)/TA \\
\hline Sales Growth $-S G R$ & (Sales at $t$-Sales at $t-1$ )Sales at $t$ \\
\hline EBITDA/Sales - EBITDA/S & $\begin{array}{l}\text { Earnings before Interest, Tax, } \\
\text { Depreciation and } \\
\text { Amortization/Sales }\end{array}$ \\
\hline Return on Equity - ROE & $\begin{array}{l}\text { Net Income/Positive Shareholders' } \\
\text { funds }\end{array}$ \\
\hline
\end{tabular}




\begin{tabular}{|l|l|}
\hline FA/TA & $\begin{array}{l}\text { Tangible Fixed Assets/Total } \\
\text { Assets }\end{array}$ \\
\hline INT/TA & $\begin{array}{l}\text { Intangible Fixed Assets/Total } \\
\text { Assets }\end{array}$ \\
\hline CA/CL & Current Assets/Current Liabilities \\
\hline Inv/TA & Inventory/Total Assets \\
\hline AR/TA & Accounts Receivable/Total Assets \\
\hline AP/TA & Accounts Payable/Total Assets \\
\hline
\end{tabular}

\section{References}

Andrade, G., and Kaplan, S. 1998. How costly is financial (not economic) distress? Evidence from highly leveraged transactions that became distressed. Journal of Finance 53: 1443-1492.

Asker, J.; Farre-Mensa, J.; and Ljungqvist, A. 2011. What do private firms look like? Data Appendix. Working paper. Social Science Research Network.

Baños-Cabbalero, S.; García-Teruel, P.; and Martínez-Solano, P. 2010. Working capital management in SMEs. Accounting and Finance 50: 511-527.

Brav, O. 2009, Access to capital, capital structure, and the funding of the firm, Journal of Finance 64: 263-308.

Burgstahler, D.; Hail, L.; and Leuz, C. 2006. The importance of reporting incentives: earnings management in European private and public firms. The Accounting Review 81: 983-1016.

Cohen, D., and Zarowin, P. 2010. Accrual-based and real earnings management activities around seasoned equity offerings. Journal of Accounting and Economics 50: 2-19.

Cuñat, V. 2007. Trade credit: suppliers as debt collectors and insurance providers. Review of Financial Studies 20: 491-527.

Deloof, M. 2003. Does working capital management affect profitability of Belgian firms? Journal of Business Finance and Accounting 30, 573-587.

Demirgüç-Kunt, A., and Maksimovic, V. 2002. Funding growth in bank-based and market-based financial systems: evidence from firm-level data. Journal of Financial Economic, 65: 337-363.

Fazzari, S. M., and Petersen, M. 1993. Working capital and fixed investment: new evidence on financing constraints. Rand Journal of Economics 24: 328-342. 
Filbeck, G.; Krueger, T.; and Preece, D. 2007. CFO magazine's working capital survey: do selected firms work for shareholders? Quarterly Journal of Economics and Business, 46: 2-22.

García-Teruel, P., and Martínez-Solano, P. 2007. Effects of working capital management on SME profitability. International Journal of Managerial Finance 3: 164-177.

García-Teruel, P., and Martínez-Solano, P. 2010. A dynamic perspective on the determinants of accounts payable. Review of Quantitative Finance and Accounting 34: 439-457.

Gentry, J.; Valdyanathan, R.; and Lee, H.W. 1990. A weighted cash conversion cycle. Financial Management 19: 90-99.

Heckman, J.J.; Ichimura, H.; and Todd, P. 1997. Matching as an econometric evaluation estimator: evidence from evaluating a job training programme. Review of Economic Studies 64: 605-654.

Hill, M.; Kelly W.; and Highfield, M. 2010. Net operating capital behavior: a first look. Financial Management 39: 783-805.

Johnson, B. 2010. Supply chain coordination and performance management with real options based relationships. Multinational Finance Journal 14: 153-188.

Jose, M.; Lancaster C.; and Stevens, J. 1996. Corporate returns and cash conversion cycles. Journal of Economics and Finance 20: 33-46.

La Porta, R.; Lopez-de-Silanes, F.; Shleifer A.; and Vishny, R. 1998. Law and finance. Journal of Political Economy 106: 1113-1155.

Lenger, S.; Ernstberger J.; and Stiebal, J. 2011. The impact of IFRS on firms' investment efficiency - European evidence on private and public firms. 2011 Illinois International Journal of Accounting Symposium paper.

Long, M.; Malitz, I.; and Ravid, A. 1993. Trade credit, quality guarantees, and product marketability. Financial Management 22: 117-127

Luo, M.M.; Lee, J.J.-Y.; and Hwang, Y. 2009. Cash conversion cycle, firm performance and stock value. Working paper. Villanova: University of Villanova.

Maksimovic, V.; Phillips G.; and Yang, L. 2010. Private and public merger waves. Working paper. Social Science Research Network.

Michaely, R., and Roberts, M. 2012. Corporate dividend policies: lessons from private firms. Review of Financial Studies 25: 711-746.

Molina, C., and Preve, L. 2009. Trade receivables policy of distressed firms and its effect on the costs of financial distress. Financial Management 38: 663-686.

Moussawi, R.; LaPlante, M.; Kieschnick R.; and Baranchuk, N. 2006. Corporate working capital management: determinants and consequences, Working paper. Dallas: University of Texas.

Niskanen, J., and Niskanen, M. 2006. The determinants of corporate trade credit policies in a bank-dominated financial environment: the case of finish small firms. European Financial Management 12: 81-102. 
Ooghe, H., and Balcaen, S. 2007. Are failure prediction models widely usable? An empirical study using a Belgian dataset. Multinational Finance Journal 11: 33-76.

Petersen, M., and Rajan, R. 1995. The effect of credit market competition on lending relationships. Quarterly Journal of Economics 110: 407-433.

Petersen, M., and Rajan, R. 1997. Trade credit: theories and evidence. Review of Financial Studies 10: 661-691.

Richards, V., and Laughlin, E. 1980. A cash conversion cycle approach to liquidity analysis. Financial Management 9: 32-38.

Rodríguez-Rodríguez, O.M., 2006. Trade credit in small and medium size firms: an application of the system estimator with panel data. Small Business Economics 27: 103-126.

Rosenbaum, P., and Rubin, D 1983. The central role of the propensity score in observation studies for causal effects. Biometrika 70: 41-55.

Rosenbaum, P., and Rubin, D. 1985. Constructing a control group using multivariate matched sampling methods that incorporate the propensity score. American Statistician 39: 33-38.

Saunders, A., and Steffen, S. 2011. The costs of being private: evidence from the loan market. Review of Financial Studies 24: 4091-4122.

Sherr, F., and Hulburt, H. 2001. The debt maturity structure of small firms. Financial Management 30: 85-111.

Shin, H.-H., and Soenen, L. 1996. Efficiency of working capital management and corporate profitability. Financial Practice and Education 8: 37-45.

Smith, J., 1987. Trade credit and information asymmetry. Journal of Finance 42, 863-869.

Smith, J., and Todd, P. 2005. Does matching overcome Lalonde's critique of nonexperimental estimators? Journal of Econometrics 125:305-353.

Strahan, P., and Weston, J. 1998. Small business lending and the changing structure of the banking industry. Journal of Banking and Finance 22: 821-845. 